\title{
Saudi University Undergraduates' Beliefs about Language Learning along Gender Lines
}

\author{
Choudhary Zahid Javid ${ }^{1} \&$ Eidah Abdullah Al-malki ${ }^{1}$ \\ ${ }^{1}$ Foreign Languages Department, Taif University, Taif, KSA \\ Correspondence: Choudhary Zahid Javid, Foreign Languages Department, Taif University, AlHaweiyeh, Taif, \\ KSA. E-mail: chzahidj@hotmail.com
}

Received: January 13, 2018

Accepted: February 7, 2018 Online Published: March 17, 2018

doi:10.5539/ijel.v8n4p39

URL: https://doi.org/10.5539/ijel.v8n4p39

\begin{abstract}
A growing mass of research has reported that each human being is different like a signature and particular characteristics based on their specific personalities have a strong effect on their language learning possibilities. Research posits that identification of EFL learners' beliefs about language learning positively affects language learning process as it helps the teachers to address to their students' learning effectively and also bears positive overbearing in case they bear some less positive beliefs. The study in hand is an attempt to investigate the beliefs of Saudi undergraduates along gender lines by using Horwitz's (1987) BALLI. The comparative analyses generated by Independent-sample T-test reveal that male participants have assigned comparatively higher values to the majority of the questionnaire items as compared to their female counterparts. The participants of this survey have exhibited the greatest gender-based differences in their beliefs about "motivation and expectations". Beliefs about "learning and communication strategies" and "the nature of language learning" have shown medium gender-based differences whereas male and female participants have seen eye to eye to each other in their perceived beliefs related to "foreign language aptitude" and difficulty of language learning. The findings of this empirical study have several pedagogical implications to revisit and modify teaching/learning practices of English language in Saudi Arabia in particular and Arab world in general. The findings will help English language teachers teaching in the KSA to understand the gender-based dimensionality of the language learning beliefs which will help them align their teaching methods to their learners' beliefs; thus, maximizing the possibilities of much sought after goal of effective and efficient ELT in the KSA.
\end{abstract}

Keywords: language learning, gender-based, beliefs

\section{Introduction}

Emphasis and interest on individual learner characteristics has grown much during the last decades and the role of learners' affective and cognitive contributions to the language learning process has been investigated in particular (Bernat \& Lloyd, 2007). It has been observed that learner's metacognitive knowledge and beliefs play an important role to shape their abilities of academic learning, thinking, reasoning and problem solving. Schoenfeld (1983) has reported that learners' belief systems, social cognitions and metacognitions are significant factors that shape their intellectual performance including learning a second/foreign language. Russell (2004) has reported that this interest in higher education teaching/learning "is partly associated with attempts to enhance the effectiveness of higher education and to improve outcomes for students" (p. 1). One major area of interest in this regard is the investigation of learners' learning beliefs.

\section{Literature Review}

In the context of learning English as a foreign language (EFL) and learning English as a second language (ESL), beliefs have been defined as "implicit theories" (Clark, 1988), "self-constructed representational systems" (Rust, 1994), and "general assumptions that students hold about themselves as learners, about factors influencing learning, and about the nature of learning and teaching" (Victori \& Lockheart, 1995, p. 224). Pajares (1992) has stated that it is such a broad term that review of relevant research would provide us with a vast list of words given below with reference to this significant construct. He has reported that beliefs are attributed to

"attitude, values, judgments, axioms, opinions, ideology, perceptions, conceptions conceptual systems, 
preconceptions, dispositions, implicit theories, explicit theories, personal theories, internal mental processes, action strategies, rules of practice, practical principles, perspectives, repertories of understanding, and social strategy" (p. 309).

Amidst the vast variety of definitions, beliefs have been preconceived as notions or metacognitive knowledge by some linguists whereas some have perceived beliefs as not merely a cognitive concept but social and cultural constructs which originated from someone's early experiences and problems (Kalajia \& Barcelos, 2003).

A growing mass of research has enumerated several factors which influence learners' beliefs. It has been reported that these factors include 1) family background (Dias, 2000; Schommer, 1990); 2) role of classroom practices and social peers (Arnold, 1999); 3) cultural background (Alexander \& Dochy, 1995); 4) interplay of prior repetitive learning experiences (Gaoyin \& Alvermann, 1995; Kern, 1995; 5) learners' individual differences (Siebert, 2003) and 6) learners' personalities (Langston \& Sykes, 1997).

Much research has suggested that learners' preconceived beliefs about learning a language would likely influence the way learning strategies are exploited and they learn a second/foreign language (Abraham \& Vann, 1987; Horwitz, 1987, 1988; Wenden, 1986, 1987). If the relationship of learners' beliefs about language learning and language learning strategy is known to EFL teachers, it will have positive overbearing resulting in a better understanding of their students' "expectation of, commitment to, success in, and satisfaction with their language classes" (Horwitz, 1988, p. 283). Mori (1999) has rather claimed that learners' positive language learning beliefs enhance their learning potential and can even compensate for learners' weaknesses. On the other hand, negative language learning beliefs may hinder their language learning success (Horwitz, 1987). This important construct has been thoroughly investigated in second and foreign language context and revealed that beliefs are quite stable within the learner, strongly held, and are not easy to be changed (Kern, 1995; Peacock, 2001). Learner beliefs seem to "have direct relevance to the understanding of student expectations of, commitment to, success in, and satisfaction with their language classes" (Horwitz, 1988, p. 283).

Cui (2014) has stated that the interest in beliefs about second/foreign language learning grew momentum in the mid-1980s. Hortwiz $(1985,1988)$ did the pioneering work in this regard and stimulated the interest in the beliefs about learner and teacher by developing an instrument: the BALLI. The BALLI was developed to identify student perceptions of a range of issues and controversies related to language learning. The development of the BALLI was based on free-recall tasks and group discussions related to both EFL and ESL learners and teachers to measure common beliefs about language learning. The instrument comprised of 34 items to measure learners' beliefs that fell into five logical categories. These include 1) the difficulty of foreign language learning; 2) foreign language aptitude; 3) the nature of language learning; 4) learning and communication strategies; and 5) motivation and expectations. The respondents of this instrument are supposed to rate each item on a 5-point Likert scale ranging from "strongly agree" to "strongly disagree". Horwitz (1985) pilot-tested this instrument with 150 first-semester foreign language students from the University of Texas at Austin to achieve reliability. The author has strongly recommended that a single composite score should not be derived from this instrument because BALLI bears multidimensionality of beliefs measured.

A growing mass of research has offered valuable insights into the fact that during the last two decades, numerous studies have investigated language learning beliefs in second language context (See for example, Yang \& Kim, 2011; Bernat, 2006) as well as in foreign language context (Al-Roomy, 2015; Al-Seghayer, 2014; Kassem, 2013; Liton, 2012; Ellis, 2008; Nikitina \& Furuoka, 2006; Tanaka \& Ellis 2003; Truitt, 1995 etc.). Review of relevant studies has also revealed that the existing studies can be categorized according to their emphasis of investigation. These include the investigation of the origin of learners' language learning beliefs (Oh, 1996; Tumposky, 1991) and the structural orientations of learners' beliefs as well as the interplay of learners' beliefs with different aspects of second/foreign language learning (Fujiwara, 2011; Rieger, 2009; Brown, 2009; Bernat, 2007; Le, 2004).

Alsamaani (2012) conducted a research to investigate the overall beliefs of Saudi university undergraduates regarding learning English as a foreign language. The findings of the study have revealed that the participants of the study held positive beliefs about English language and its learning dynamics. It has also been reported that beliefs regarding the communication strategies and nature of language learning were affected by their previous experiences that they had while they were at school. The results of this empirical study have concluded that it is important to understand learners' beliefs to identify other factors which are related to learning and teaching practices. It has been reported that the students' expectations and motivational orientations towards the target language, the teachers' teaching methods and the appropriacy language learning materials are the factors which have been identified in this regard. Kassem (2013) investigated Saudi freshmen 
majoring in business administration to identify their learning beliefs and attitudes. A comparative analysis was conducted between a group of English-major students and another group majoring in business administration. The findings of the study have exhibited that English-major students bore stronger beliefs and attitudes toward EFL learning. The business administration group also showed reasonably positive beliefs towards English language and did not perceive English as a threat to their culture or mother tongue. The results have further revealed that business administration group did not show positive beliefs towards low factors which were self-efficacy and the difficulty and nature of learning English. Al-Seghayer (2014) conducted an exploratory study by investigating Saudi university EFL learners from King Muhammad University and stated that beliefs of Saudi students represented by the participants of his study have been identified as the major obstacles which adversely affect English language learning among Saudi EFL learners. He has further revealed that Saudi EFL learners bore negative beliefs towards English because of several internal and external factors which include their beliefs about English language, their past learning experiences as well as expectations towards learning English. Liton (2012) investigated Saudi intermediate students to identify their motivational orientations toward English language. The results of the study indicated that the participants felt demotivated because of inappropriate classroom proceedings. The study has also suggested several steps to ensure high motivation among Saudi EFL learners at intermediate level. It has been suggested that it is important to exploit technological facilities inside the classrooms, exploit authentic materials, use varied teaching methods as well as start English language teaching in early stages.

\section{Method}

\subsection{Research Questions}

The study in hand is an attempt to find out the answers to the following research questions:

1) What are the beliefs of male Saudi University Undergraduates studying at Taif University towards language learning?

2) What are the beliefs of female Saudi University Undergraduates studying at Taif University towards language learning?

3) What gender-based differences exist in the beliefs of Saudi University Undergraduates studying at Taif University towards language learning?

\subsection{Research Hypothesis}

The present study is governed by the following null hypothesis:

Ho: There does not exist statistically significant gender-based differences in the beliefs of Saudi

University Undergraduates studying at Taif University towards language learning.

\subsection{Research Design}

This study is a survey research which has investigated beliefs of Saudi University Undergraduates (male and female) about language learning. This survey was basically descriptive in nature in which the perceptions of the participants of this study were recorded and quantitatively analysed to present the findings of this study.

\subsection{Participants}

This study used random sampling to collect data. Arabic translation of Likert-scale BALLI was administered to randomly selected $160(\mathrm{n}=162$ : male $=87 \&$ female $=75)$ Saudi University Undergraduates studying in Foreign Languages Department, Taif university in the regular teaching sessions.

\subsection{Instrumentation}

Cui (2014) has reported that review of relevant research indicated that "with regard to research instruments, there are two lines of research on learner language learning beliefs" (p. 26). Majority of studies have employed the BALLI to investigate learners' beliefs whereas some studies have also used questionnaires devised by researchers themselves. The present study used "the BALLI" which was originally developed by Horwitz (1985) and has been extensively used in host of studies worldwide. This instrument was mainly developed to identify student perceptions towards a range of issues and controversies related to language learning. The instrument comprised of 34 items to measure learners' beliefs that fell into five logical categories. These include 1) the difficulty of foreign language learning; 2) foreign language aptitude; 3) the nature of language learning; 4) learning and communication strategies; and 5) motivation and expectations. The participants would rank rate each item on a 5-point Likert scale ranging from "strongly agree" to "strongly disagree".

Horwitz (1985) pilot-tested this instrument with 150 first-semester foreign language students from the 
University of Texas at Austin to measure its reliability. Several later studies also determined the internal validity (reliability alphas) of the BALLI in various contexts and reported on overall satisfactory or acceptable reliability alphas. Fujiwara (2011) has piloted and reported an acceptable level of Cronbach alpha reliability ranging from 0.59 to 0.49 for its various sections. Yang (1999) has reported a reliability alpha range of 0.71 to 0.52 . The BALLI was used by Cui (2014) who subjected it to exploratory factor analysis to determine reliability for its structural dimensions and calculation of their respective Cronbach's alphas. It was pilot tested with a Chinese population in the USA and the results have exhibited an accepted level of BALLI's internal validity, with the reliability alphas ranging between 0.62 to 0.48 .

\subsection{Data Collection}

The researchers have employed the standard version of the BALLI developed by Horwitz (1984) to the target population of the study. Considering the fact that the questionnaire items in English might hinder the participants' understanding, the researchers translated it into Arabic Language and sent it to experts to verify its translation. The Arabic version has been administered to the participants of this empirical study.

\subsection{Data Analysis}

The data generated through the BALLI was analyzed by using version 20 of Statistical Package for Social Sciences (SPSS). Independent-Samples T-test was run to calculate the descriptive analysis as well as to identify any significant differences in the perceptions of both participatory groups, i.e., male and female Saudi university undergraduates studying at FLD, Taif university.

\section{Results and Discussion}

Table 1. Foreign language aptitude

\begin{tabular}{|c|c|c|c|c|c|c|c|c|}
\hline & & Group & $\mathbf{n}$ & $\mathbf{M}$ & $\mathbf{T}$ & Df & p value & \\
\hline \multirow[t]{2}{*}{1} & \multirow{2}{*}{$\begin{array}{l}\text { It is easier for children than adults to learn a foreign } \\
\text { Language }\end{array}$} & Male & 87 & 4.252 & .636 & 160 & .526 & $\mathrm{p}>0.05$ \\
\hline & & Female & 75 & 4.146 & .634 & 154.0 & .527 & \\
\hline \multirow[t]{2}{*}{2} & \multirow{2}{*}{$\begin{array}{l}\text { Some people are born with special ability which helps } \\
\text { them learn a foreign language }\end{array}$} & Male & 87 & 3.310 & 2.236 & 160 & .027 & $\mathrm{p}<0.05$ \\
\hline & & Female & 75 & 2.933 & 2.214 & 148.5 & .028 & \\
\hline \multirow[t]{2}{*}{10} & \multirow{2}{*}{$\begin{array}{l}\text { It is easier for someone who speaks a foreign language to } \\
\text { learn another one }\end{array}$} & Male & 87 & 3.563 & -1.61 & 160 & .109 & $\mathrm{p}>0.05$ \\
\hline & & Female & 75 & 3.786 & -1.60 & 155.5 & .110 & \\
\hline \multirow[t]{2}{*}{15} & \multirow[t]{2}{*}{ I have foreign language aptitude } & Male & 87 & 4.344 & .707 & 160 & .480 & $\mathrm{p}>0.05$ \\
\hline & & Female & 75 & 4.253 & .694 & 137.4 & .489 & \\
\hline \multirow[t]{2}{*}{22} & \multirow[t]{2}{*}{ Women are better than men at learning foreign languages } & Male & 87 & 2.735 & -3.56 & 160 & .000 & $\mathrm{p}<0.05$ \\
\hline & & Female & 75 & 3.373 & -3.61 & 159.8 & .000 & \\
\hline \multirow[t]{2}{*}{29} & \multirow{2}{*}{$\begin{array}{l}\text { People who are good at math and science are not good at } \\
\text { learning foreign languages }\end{array}$} & Male & 87 & 2.942 & 4.517 & 160 & .000 & $\mathrm{p}<0.05$ \\
\hline & & Female & 75 & 2.226 & 4.558 & 159.8 & .000 & \\
\hline \multirow[t]{2}{*}{32} & \multirow{2}{*}{$\begin{array}{l}\text { People who speak more than one language well are very } \\
\text { Intelligent }\end{array}$} & Male & 87 & 4.011 & 1.087 & 160 & .279 & $\mathrm{p}>0.05$ \\
\hline & & Female & 75 & 3.853 & 1.071 & 142.2 & .286 & \\
\hline \multirow[t]{2}{*}{33} & \multirow[t]{2}{*}{ Saudis are good at learning foreign languages } & Male & 87 & 3.563 & 1.526 & 160 & .129 & $\mathrm{p}>0.05$ \\
\hline & & Female & 75 & 3.320 & 1.517 & 152.0 & .131 & \\
\hline \multirow[t]{2}{*}{34} & \multirow[t]{2}{*}{ Everyone can learn to speak a foreign language } & Male & 87 & 3.793 & 1.040 & 160 & .300 & $\mathrm{p}>0.05$ \\
\hline & & Female & 75 & 3.600 & 1.046 & 159.2 & .297 & \\
\hline
\end{tabular}

Table 1 presents the data generated through independent-samples T-test for BALLI items related to foreign language aptitude. Among these 9 items, both male and female participants ranked "I have foreign language aptitude" the highest with a mean of more than 4.25 contradicting the findings of Bernat \& Lioyd (2007). The second highest mean has been assigned to the first item agreeing that "it is easier for children than adults to learn a foreign language". The finding is in line with the results of Bernat \& Lioyd (2007) who have reported that Asian EFL learners at an Australian university favoured these items. The data has reported the third highest mean value for the statement: "people who speak more than one language well are very intelligent". An interesting finding is that all these most favored items have not exhibited any statistically significant difference in the perceptions of the male and female participants of this survey.

Three items have shown significant gender-based differences and all these items are the ones which have been least favored by the participants of this survey. The participants did not agree to the statement that "people who are good at math and science are not good at learning foreign languages" with extremely low mean of less than 3 . Among the other two least preferred items are the ones that sought their perception regarding the "women being 
better than men in learning a foreign language" and the hypothesis that "some people are born with special ability to learn a foreign language".

The comparative analyses of the responses have informed that male have assigned higher mean to almost all items of this category as compared to the responses of their female counterparts contradicting the findings of Daif-Allah (2012) where female cohort has been reported to assign higher ranking to foreign language aptitude items. The comparative analyses of independent-samples t-test has revealed that only three items $(2,22 \& 29)$ bore gender-based differences. The findings have partially confirmed the findings of Daif-Allah (2012) who has reported that four items in this category $(10,15,22 \& 32)$ bore statistically significant differences as reported by Saudi EFL leaners at Qaseem university. But the female participants of both studies have assigned significantly higher ranking as compared to their male counterparts to the item stating that women are better than men at learning foreign languages.

Table 2. Difficulty of language learning

\begin{tabular}{|c|c|c|c|c|c|c|c|c|}
\hline & & Group & $\mathbf{n}$ & $\mathbf{M}$ & $\mathbf{T}$ & Df & p value & \\
\hline \multirow[t]{2}{*}{3} & \multirow[t]{2}{*}{ Some languages are easier to learn than others. } & Male & 87 & 4.195 & -.209 & 160 & .835 & $\mathrm{p}>0.05$ \\
\hline & & Female & 75 & 4.2267 & -.207 & 151.7 & .836 & \\
\hline \multirow[t]{2}{*}{4} & The language I am trying to learn is: 1) a very difficult & Male & 87 & 3.528 & 2.279 & 160 & .024 & $\mathrm{p}<0.05$ \\
\hline & $\begin{array}{l}\text { language, 2) a difficult language, 3) a language of } \\
\text { medium difficulty, 4) an easy language, 5) a very easy } \\
\text { language. }\end{array}$ & Female & 75 & 3.280 & 2.336 & 154.3 & .021 & \\
\hline \multirow[t]{2}{*}{6} & I believe that I will ultimately learn to speak this language & Male & 87 & 4.551 & -.256 & 160 & .798 & $\mathrm{p}>0.05$ \\
\hline & very well. & Female & 75 & 4.573 & -.259 & 159.9 & .796 & \\
\hline \multirow[t]{3}{*}{14} & If someone spends an hour a day learning a language, & Male & 87 & 2.448 & .241 & 160 & .810 & $\mathrm{p}>0.05$ \\
\hline & $\begin{array}{l}\text { how long would it take him/her to become fluent? 1) less } \\
\text { than one year, 2) 1-2 years, 3) 3-5 years, 4) 5-10 years, 5) }\end{array}$ & Female & 75 & 2.413 & .243 & 159.5 & .809 & \\
\hline & you cannot learn a language in 1 hour a day. & & & & & & & \\
\hline \multirow[t]{2}{*}{24} & It is easier to speak than understand a foreign language. & Male & 87 & 3.413 & 1.826 & 160 & .070 & $\mathrm{p}>0.05$ \\
\hline & & Female & 75 & 3.106 & 1.819 & 153.6 & .071 & \\
\hline \multirow[t]{2}{*}{28} & It is easier to read and write this language than to speak & Male & 87 & 2.816 & .640 & 160 & .523 & $\mathrm{p}>0.05$ \\
\hline & and understand it. & Female & 75 & 2.706 & .644 & 159.2 & .521 & \\
\hline
\end{tabular}

As far the responses of the participants regarding the difficulty of language learning are concerned, the highest mean has been reported for their belief that "they will ultimately learn to speak the target language well" followed by their perception that "some languages are easier to learn" as compared to some other languages confirming the findings of Bernat \& Lioyd (2007). Mean value of less than 2.5 has been reported for the item 14 informing that both male and female participants believe that 3-5 years are needed to learn English language if a learner spends one hour each day. The respondents have not agreed to the notion that it is easier to read and write in the target language than to speak and understand it by assigning low value of less than 3 to items 28 . The findings are in line with the results presented by Javid, Farooq, \& Khan (2013) who have reported that Saudi EFL learners do not prefer to do language activities which involve reading and writing skills.

In this category only item 4 bears gender-based differences highlighting that male participants consider English more difficult to learn as compared to female participants. The results bear strong contradiction with the perceptions of Saudi EFL learners from Qaseem university who reported significant gender-based differences in four items $(3,6,24 \& 28)$ in this category Daif-Allah (2012). 
Table 3. The nature of language learning

\begin{tabular}{|c|c|c|c|c|c|c|c|c|}
\hline & & Group & $\mathbf{n}$ & M & $\mathbf{T}$ & Df & p value & \\
\hline \multirow[t]{2}{*}{5} & \multirow{2}{*}{ The structure of English is different from that of Arabic. } & Male & 87 & 4.252 & -.630 & 160 & .530 & $\mathrm{p}>0.05$ \\
\hline & & Female & 75 & 4.333 & -.632 & 158.0 & .528 & \\
\hline \multirow[t]{2}{*}{8} & \multirow{2}{*}{$\begin{array}{l}\text { It is necessary to know the foreign culture in order to } \\
\text { speak the foreign language. }\end{array}$} & Male & 87 & 3.632 & 2.039 & 160 & .043 & $\mathrm{p}<0.05$ \\
\hline & & Female & 75 & 3.306 & 2.010 & 143.4 & .046 & \\
\hline 1 & \multirow{2}{*}{$\begin{array}{l}\text { It is better to learn a foreign language in the foreign } \\
\text { country. }\end{array}$} & Male & 87 & 4.275 & .242 & 160 & .809 & $\mathrm{p}>0.05$ \\
\hline 1 & & Female & 75 & 4.240 & .243 & 158.4 & .808 & \\
\hline 1 & \multirow{2}{*}{$\begin{array}{l}\text { Learning a foreign language is mostly a matter of learning } \\
\text { a lot of new vocabulary words. }\end{array}$} & Male & 87 & 3.908 & 2.507 & 160 & .013 & $\mathrm{p}<0.05$ \\
\hline 6 & & Female & 75 & 3.533 & 2.486 & 149.8 & .014 & \\
\hline 2 & \multirow{2}{*}{$\begin{array}{l}\text { Learning a foreign language is mostly a matter of learning } \\
\text { a lot of grammatical rules. }\end{array}$} & Male & 87 & 3.379 & .492 & 160 & .623 & $\mathrm{p}<0.05$ \\
\hline 0 & & Female & 75 & 3.306 & .482 & 136.9 & .630 & \\
\hline 2 & \multirow{2}{*}{$\begin{array}{l}\text { Learning a foreign language is different from learning } \\
\text { other school subjects. }\end{array}$} & Male & 87 & 4.206 & 3.567 & 160 & .000 & $\mathrm{p}<0.05$ \\
\hline 5 & & Female & 75 & 3.680 & 3.496 & 136.5 & .001 & \\
\hline 2 & \multirow{2}{*}{$\begin{array}{l}\text { Learning a foreign language is mostly a matter of } \\
\text { translating from English. }\end{array}$} & Male & 87 & 3.298 & 1.189 & 160 & .236 & $\mathrm{p}>0.05$ \\
\hline 6 & & Female & 75 & 3.133 & 1.193 & 158.4 & .235 & \\
\hline
\end{tabular}

"The structure of English is different from that of Arabic" has received the highest mean value followed by a completely unanimous response by both groups that "it is better to learn a foreign language in the foreign country" endorsing the results of Bernat \& Lioyd (2007) who have informed that a vast majority of $89 \%$ of male and female participants of their study has favored this belief. The least ranking has indicated that the participants do not believe that "learning a foreign language is only a matter of translating from English". The second least preference has been reported for the item that sought their response towards the assumption that "learning a foreign language is mostly a matter of grammar rules". The findings contracts with the findings of Daif-Allah (2012) who has reported that Saudi EFL learners at Qaseem university have ranked both these items quite high with $79 \%$ of the participants strongly agreeing to these statements.

The data analyses have exhibited gender-based differences in three items $(8,16 \& 25)$ which are related to difference of English and Arabic, learning new vocabulary and difference of language learning from learning other subjects. The findings are in opposition with the results presented by Daif-Allah (2012) who has pointed out that the participants of his study have also shown significant difference in three items but different one (i.e., 5 , $11 \& 26)$.

Table 4. Learning and communication strategies

\begin{tabular}{lllllllll}
\hline & Group & $\mathbf{n}$ & $\mathbf{M}$ & $\mathbf{T}$ & Df & p value \\
\hline 7 & It is important to speak a foreign language with an & Male & 87 & 4.149 & 1.796 & 160 & .074 & $\mathrm{p}>0.05$ \\
& excellent pronunciation and accent. & Female & 75 & 3.866 & 1.795 & 156.0 & .075 & \\
9 & You should not say anything in a foreign language until & Male & 87 & 2.252 & -1.20 & 160 & .230 & $\mathrm{p}>0.05$ \\
& you can say it correctly. & Female & 75 & 2.466 & -1.20 & 157.0 & .230 & \\
1 & If I heard some people speaking the language I am trying & Male & 87 & 4.229 & 2.548 & 160 & .012 & $\mathrm{p}<0.05$ \\
2 & to learn, I would go up to them so that I could practice & Female & 75 & 3.853 & 2.515 & 145.1 & .013 & \\
& speaking the language. & & & & & & \\
1 & It is o.k. to guess if you do not know a word in the & Male & 87 & 4.264 & 3.039 & 160 & .003 & $\mathrm{p}<0.05$ \\
3 & foreign language. & Female & 75 & 3.906 & 3.024 & 152.7 & .003 & \\
1 & It is important to repeat and practice a lot. & Male & 87 & 4.781 & 2.384 & 160 & .018 & $\mathrm{p}<0.05$ \\
7 & & Female & 75 & 4.520 & 2.310 & 121.9 & .023 & \\
1 & I feel self-conscious speaking the foreign language in & Male & 87 & 2.620 & -2.21 & 160 & .028 & $\mathrm{p}<0.05$ \\
8 & front of other people. & Female & 75 & 3.040 & -2.22 & 159.0 & .028 & \\
1 & If you are allowed to make mistakes in the beginning it & Male & 87 & 2.747 & .285 & 160 & .776 & $\mathrm{p}>0.05$ \\
9 & will be hard to get rid of them later on. & Female & 75 & 2.680 & .285 & 157.8 & .776 & \\
2 & It is important to practice in the language laboratory. & Male & 87 & 3.781 & -.263 & 160 & .793 & $\mathrm{p}>0.05$ \\
1 & & Female & 75 & 3.826 & -.260 & 149.5 & .795 & \\
\hline
\end{tabular}

Table 4 details the participants' responses towards learning and communication strategies and both groups have assigned an extremely high ranking to the item 17 (It is important to repeat and practice a lot.). The second highest ranking has been reported to the strategy of guessing for new words' followed by their willingness to seek maximum opportunities to practice the target language. The same trend has been reported by Bernat \& Lloyd 
(2007) with an extremely high preference of $92 \%$ and $77 \%$ by Asian EFL learners respectively for these items. The findings confirm the results of Javid, Farooq, \& Gulzar (2013) who have revealed that Saudi English-major university undergraduates have strongly agreed that it is extremely important to extensively practice the target language for better learning and that they always try to avail the opportunities to repeat and practice the target language. The same findings have been reported by Javid, Al-thubaiti, \& Uthman (2013) who have investigated language learning strategies of Saudi EFL learners at Taif university.

Both groups have seen eye to eye to each other by assigning the least mean to the strategy of "should not saying anything in the foreign language until it can be said correctly" partially verifying the results of Javid (2014) whose study has revealed that Saudi EFL leaners have assigned medium high ranking to the item "I don't worry about making mistake". This pedagogical positive attitude of the participants of the present study seems encouraging and promising. The other two lowest ranking items have been 19 and 18 stating that if "learners are allowed to make mistakes in the beginning it will be hard to get rid of them later on" and they do not feel "self-conscious while speaking the foreign language in front of other people". This positive trend verifies the findings of Javid (2014) who has stated that Saudi EFL learners strongly like those teachers who motivates and encourages them to actively participate in classroom activates. Least preference to these 3 items indicate a very positive attitude of Saudi EFL learners that do not feel shy to practice the target language even when they are not proficient in it.

The male participants of this study have assigned significantly higher mean values to items $12,13,17$ and 18 as compared to their female counterparts. The findings do not match with gender-based differences reported by Daif-Allah (2012) whose study has revealed differences in the perceptions of his male and female respondents for this category but in items $7,9,13$ and 21 .

Table 5. Motivations and expectations

\begin{tabular}{lllllllll}
\hline & & Group & $\mathbf{n}$ & $\mathbf{M}$ & T & Df & p value \\
\hline \multirow{2}{*}{23} & If I get to speak this language very well, I will & Male & 87 & 4.563 & 2.721 & 160 & .007 & $\mathrm{p}<0.05$ \\
& have many opportunities to use it. & Female & 75 & 4.253 & 2.639 & 123.3 & .009 & \\
27 & If I learn to speak this language very well, it & Male & 87 & 4.436 & 2.632 & 160 & .009 & $\mathrm{p}<0.05$ \\
& will help me get a good job. & Female & 75 & 4.120 & 2.604 & 147.4 & .010 & \\
\multirow{2}{*}{30} & Saudis think that it is important to speak a & Male & 87 & 3.770 & 2.326 & 160 & .021 & $\mathrm{p}<0.05$ \\
& foreign language. & Female & 75 & 3.386 & 2.308 & 150.7 & .022 & \\
\multirow{3}{*}{31} & I would like to learn this language so that I can & Male & 87 & 4.310 & 1.373 & 160 & .172 & $\mathrm{p}>0.05$ \\
& get to know its speakers better. & Female & 75 & 4.106 & 1.362 & 150.2 & .175 & \\
\hline
\end{tabular}

Comparative data analyses related to four items of learners' motivation and expectations have been detailed in table 5. Items 23 and 27 have received highest ranking by both groups highlighting the participants' belief of the availability of frequent opportunities of speaking/practicing the target language and the fact that higher proficiency in the target language would help them get a good job. This seems an extremely encouraging finding that indicates that Saudi EFL learners are aware of the vast opportunities of English language learning possibilities because of the enhanced online resources which are easily available to the interested and motivated learners. An overwhelming majority of Asian EFL learners have also agreed to these two items as reported by Bernat \& Lioyd (2007). The finding coincides with the previous research conducted in the same academic context as Al-asmari \& Javid (2011) have reported that Saudi EFL learners bear high instrumental motivational factor of the possibility of getting an attractive job if they possess high English language proficiency. The other two items sought the participants' response towards Saudi's belief that it is important to speak and foreign language and that they want to learn English to know the native speakers better. Both these items have revealed medium liking by the participants as indicated by low mean values assigned to these items.

Results have revealed significant gender-based differences in the first three items related to motivation and expectations which is in line with the findings of Daif-Allah (2012) who has also indicated that his participants bore gender-based differences in all four items of this category.

\section{Conclusions and Recommendations}

The study in hand is an attempt to investigate the beliefs of Saudi undergraduates along gender lines by using Horwitz's (1985) BALLI. The comparative analyses generated by Independent-sample T-test reveal that male participants have assigned comparatively higher values to the majority of the questionnaire items as compared to their female counterparts. The results have also reported that the participants have favoured the beliefs related to "motivations and expectations" the most followed by their beliefs about "learning and communication strategies". 
Third most favoured beliefs have been related to "the nature of language and learning". The beliefs about "foreign language aptitude" and "difficulty of language learning" have been ranked the lowest respectively.

The participants of this survey have exhibited the greatest gender-based differences in their beliefs about "motivation and expectations". Beliefs about "learning and communication strategies" and "the nature of language learning" have shown medium gender-based differences whereas male and female participants have seen eye to eye to each other in their perceived beliefs related to "foreign language aptitude" and difficulty of language learning with least gender-based differences. The male cohort of this survey have agreed that some people are born with special ability to learn a foreign language whereas the female participants didn't agree to this hypothesis. Women are better language learners has been favoured more by the female and the male have shown significantly higher agreement to the belief that people who speak more than one language are more intelligent. Gender-based differences remained significant for the belief that understanding the culture of target language is important for learning a language in favour of male participants. Likewise, male cohort have also ranked "learning a foreign language is different from learning other subjects" significantly higher as compared to female participants. The results have also shown that gender-based differences exist on the degree of enjoyment they experience in practicing the target language with native speakers in favour of male participants who have assigned significantly higher mean exhibiting their preference to avail this kind of opportunity. Lower preference by the female participants might be due to their cultural shyness to interact with strangers. Furthermore, male-favoured gender-based differences were found in their attitude to guess the meaning of unknown words, repetition and practice of target language and consciousness while speaking English in front of other people. Significant difference has also been found in their beliefs about motivation and expectations. Male participants have shown significantly higher agreement to the fact that many opportunities would be available to them if they want to learn English. Same trend has been manifested in the comparative analyses of the item related to their instrumental motivation of learning English for getting a good job. Female participants, on the other hand, have assigned lower values to these two items as well as to the items stating that Saudis consider it important to speak a foreign language. The overall result of independent-samples t-test partially accept the null hypothesis set for this empirical study as 15 out of the total 34 items reported statistically significant difference in the perceptions of the male and female cohort.

The findings of this empirical study have several pedagogical implications to revisit and modify teaching/learning practices of English language in Saudi Arabia in particular and Arab world in general. The findings of this empirical survey will help English language teachers in the KSA to understand the gender-based dimensionality of the language learning beliefs which will help them align their teaching methods and practices to their learners' beliefs; thus, maximizing the possibilities of much sought after goal of effective and efficient English language teaching in the KSA. Identification of Saudi EFL learners' beliefs will also inform all the stake holders involved in developing ELT material to make appropriate changes which correspond to Saudi EFL learners' needs and preferences. It is highly recommended to include more interactive activities in the language classes to increase learning possibilities by constantly using the target language in the classrooms. It also seems extremely important to train and encourage Saudi EFL learners to exploit vast online resource to compensate for limited opportunities of practicing the target language in the Saudi Society. The present study has emphasized to investigate gender-based differences related to Saudi university undergraduates' language learning beliefs but considering its smaller size, the findings cannot be generalized to the whole population of Saudi EFL learners. Therefore, it is recommended that additional investigations are needed to better understand the nature of language beliefs and their pedagogical implications.

\section{References}

Abraham, R. G., \& Vann, R. J. (1987). Strategies of two language learners: a case study. In A. L. Wenden \& J. Rubin (Eds.), Learner Strategies in Language Learning (pp. 85-102). Englewood Cli€s, NJ: Prentice-Hall.

Al-asmari, A. A., \& Javid, C. Z. (2011). Motivational Constructs: A Cross Sectional Study of EFL Students at Taif University. Journal of Social Sciences \& Humanities, XIX(2), 73-104.

Alexander, P. A., \& Dochy, F. J. (1994). Adults' views about knowing and believing. In R. Garner \& P. A. Alexander (Eds.), Beliefs about text and about instruction with text (pp. 223-244). Hillsdale, NJ: Erlbaum.

Al-Roomy, M. (2015). Evaluating Saudi University Students' Beliefs about Learning English. International Journal of English Linguistics, 5(1), 22-31. https://doi.org/10.5539/ijel.v5n1p22

Alsamaani, A. (2012). Assessing Saudi Learners' Beliefs about English Language Learning. International Journal of English and Education, 1(2), 31-55. 
Al-Seghayer, K. (2014). The Four Most Common Constraints Affecting English Teaching in Saudi Arabia. International Journal of English Linguistics, 4(5), 17-26. http://dx.doi.org/10.5539/ijel.v4n5p17

Arnold, J. (1999). Affect in language learning. Cambridge: Cambridge University Press.

Bernat, E. (2006). Assessing EAP learners' Beliefs about Language Learning in the Australian Context. Asian EFL Journal, 8(2), Article 9. Retrieved from http://www.asian-efl-journal.com/June_06_eb.php

Bernat, E. (2007). EFL learners' and teachers' mismatched beliefs about language learning in an academic setting. In C. Gitsaki (Ed.), Language and Languages: Global and Local Tensions (pp. 171-184). Newcastle, UK: Cambridge Scholars Publishing.

Bernat, E., \& Lloyd, R. (2007). Exploring the Gender Effect on EFL Learners' Beliefs about Language Learning. Australian Journal of Educational \& Developmental Psychology, (7), 79-91.

Brown, A. V. (2009). Students' and teachers' perceptions of effective foreign language teaching: A comparison of ideals. The Modern Language Journal, 93, 46-60. https://doi.org/10.1111/j.1540-4781.2009.00827.x

Clark, C. (1988). Asking the right questions about teacher preparation: Contributions of research on teaching thinking. Educational Researcher, 17, 5-12. https://doi.org/10.3102/0013189X017002005

Cui, Y. (2014). Beliefs about Language Learning: A Study of Post-Secondary Non-Native Learners of Chinese and Teachers of Chinese in North America. A Dissertation Submitted in Partial Fulfillment of the Requirements for the Degree of DOCTOR OF PHILOSOPHY in the Department of Curriculum and Instruction, University of Victoria.

Daif-Allah, A. S. (2012). Beliefs about Foreign Language Learning and their Relationship to Gender. English Language Teaching, 5(10), 20-33. https://doi.org/10.5539/elt.v5n10p20

Dias, R. L. (2000). Lebanese students' beliefs about learning English and French: A study of university students in a multilingual context. Dissertation Abstracts International, 62(02), 497A (UMI No. 3004253).

Ellis, R. (2008). Learner Beliefs and Language Learning. Asian EFL Journal, 10(4). Retrieved from http://www.asian-efl-journal.com/December_08_re.php

Fujiwara, T. (2011). Language learning beliefs of Thai EFL university students: Dimensional structure and cultural variations. Electronic Journal of Foreign Language Teaching, 8(1), 87-107.

Gaoyin, Q., \& Alvermann, D. (1995). Role of epistemological beliefs and learned helplessness in secondary school students' learning science concepts from text. Journal of Educational Psychology, 87(2), 282-292. https://doi.org/10.1037/0022-0663.87.2.282

Horwitz, E. K. (1984). What ESL students believe about language learning. Paper presented at the Annual meeting of TESOL, Houston, TX: University of Texas.

Horwitz, E. K. (1985). Using student beliefs about language learning and teaching in the foreign language $\begin{array}{lllll}\text { methods course. Foreign } & \text { Language }\end{array}$ http://dx.doi.org/10.1111/j.1944-9720.1985.tb01811.x

Horwitz, E. K. (1987). Surveying student beliefs about language learning. In A. Wenden \& J. Rubin (Eds.), Learner strategies in language learning (pp. 119-129). London, UK: Prentice-Hall International.

Horwitz, E. K. (1988). The beliefs about language learning of beginning university foreign language students. The Modern Language Journal, 72, 182-193. http://dx.doi.org/10.1111/j.1540-4781.1988.tb04190.x

Javid, C. Z., Farooq, U., \& Gulzar, M.A. (2012). Saudi English-major undergraduates and English Teachers' perceptions regarding effective ELT in the KSA: A Comparative Study. European Journal of Scientific Research, 85(1), 55-70. $\quad$ Retrieved from http://www.europeanjournalofscientificresearch.com/ISSUES/EJSR_85_1.htm

Javid, C. Z., Farooq, U., \& Umer, M. (2013). An Investigation of Saudi EFL learners' Writing Problems: A Case Study along Gender-lines. Kashmir Journal of Language Research, 16(1), 179-203.

Javid, C. Z., Al-thubaiti, T. S., \& Uthman, A. (2013). Effects of English Language Proficiency on the Choice of Language Learning Strategies by Saudi English-major Undergraduates. English Language Teaching, 6(1), 35-47. http://dx.doi.org/10.5539/elt.v6n1p35

Javid, S. Z. (2014). Measuring Language Anxiety in an EFL Context. Journal of Education and Practice, 5(25), 180-193. Retrieved from http://www.iiste.org/Journals/index.php/JEP/article/view/15295 
Javid, C. Z. (2014). Perceptive Determination of Saudi EFL Learners about the Characteristics of an Ideal English Language Teacher. Research on Humanities and Social sciences, 4(8), 42-53. Retrieved from http://www.iiste.org/Journals/index.php/RHSS/article/view/12477

Kalaja, P., \& Barcelos, A. M. F. (2003). Introduction. In P. Kalaja \& A. M. F. Barcelos (Eds.), Beliefs about SLA: New research approaches (pp. 1-4). Dordrecht: Kluwer. https://doi.org/10.1007/978-1-4020-4751-0

Kassem, H. (2013). English as a foreign Language Beliefs and Attitudes of Saudi College English and non-English Major. Arab World English Journal, 4(4), 400-419.

Kern, R. G. (1995). Students' and teachers' beliefs about language learning. Foreign Language Annals, 28, 71-92. https://doi.org/10.1111/j.1944-9720.1995.tb00770.x

Langston, C. A., \& Sykes, W. E. (1997). Beliefs and the Big Five: Cognitive bases of broad individual differences in personality. Journal of Research in Personality, 31, 141-165. https://doi.org/10.1006/jrpe.1997.2178

Le, J. (2004). Affective characteristics of American students studying Chinese in China: A study of heritage and non-heritage learners' beliefs and foreign language (Doctoral dissertation). Retrieved from ProQuest Dissertations and Theses database. (UMI No. 3150676).

Liton, H. (2012). Developing EFL Teaching and Learning Practices in Saudi Colleges: A Review. International Journal of Instruction, 5(2), 129-152.

Mori, Y. (1999). Epistemological beliefs and language learning beliefs: What do language learners believe about their learning? Language Learning, 49(3), 377-415. https://doi.org/10.1111/0023-8333.00094

Nikitina, L., \& Furuoka, F. (2006). Re-examining Horwitz's Beliefs about Language Learning Inventory (BALLI) in the Malaysian Context. Electronic Journal of Foreign Language Teaching, 3(2), 209-219. Retrieved from http://e-flt.nus.edu.sg/v3n22006/nikitina.htm

Oh, M. J. (1996). Beliefs about language learning and foreign language anxiety: A study of American university, students learning Japanese (Doctoral dissertation). Retrieved from ProQuest Dissertations and Theses database. (UMI No. 3050689).

Pajares, M. F. (1992). Teachers' beliefs and educational research: Cleaning up a messy construct. Review of Educational Research, 62(3), 307-332. https://doi.org/10.3102/00346543062003307

Peacock, M. (1999). Beliefs about language learning and their relationship to proficiency. International Journal of Applied Linguistics, 9(2), 247-265. https://doi.org/10.1111/j.1473-4192.1999.tb00175.x

Peacock, M. (2001). Pre-service ESL teachers' beliefs about second language learning: a longitudinal study. System, 29(2), 177-195. https://doi.org/10.1016/S0346-251X(01)00010-0

Rieger, B. (2009). Hungarian university students' beliefs about language learning: A questionnaire study. WoPaLP, 3, 97-113.

Russell, A. (2004). Zayed University Students' Teaching and Learning Beliefs and Preferences: An analysis based on the surface versus deep learning approach. Learning and Learning in Higher Education: Gulf Perspectives, Article 1, 1. Retrieved from http://www.zu.ac.ae/lthe/vol1/lthe01_01.pdf

Rust, F. (1994). The first year of teaching. It's not what they expected. Teaching and Teacher Education, 10, 205-217. https://doi.org/10.1016/0742-051X(94)90013-2

Schoenfeld, A. H. (1983). Beyond the purely cognitive: Belief systems, social cognitions, and metacognitions as driving forces in intellectual performance. Cognitive Science, 7(4), 329-363. https://doi.org/10.1207/s15516709 $\operatorname{cog} 0704 \_3$

Schommer, M. (1990). Effects of beliefs about the nature of knowledge on comprehension. Journal of Educational Psychology, 82(3), 498-504. https://doi.org/10.1037/0022-0663.82.3.498

Siebert, L. (2003). Student and teacher beliefs about language learning. Foreign Language Annals, 33(4), 394-420.

Tanaka, K. \& Ellis, R. (2003). Study abroad, language proficiency, and learner beliefs about language learning. JALT Journal, 25, 63-85.

Truitt, S. N. (1995). Beliefs about Language Learning: A Study of Korean University Students Learning English. Texas Papers in Foreign Language Education, 2(1), 1-16. Retrieved from http://www.eric.ed.gov/PDFS/ED416703.pdf 
Tumposky, N. J. (1991). Student beliefs about language learning: A cross-cultural study. Carleton Papers in Applied Language Studies, 8, 50-65.

Victori, M., \& Lockhart, W. (1995). Enhancing metacognition in self-directed language learning. System, 23 (Special issue on Learner Autonomy), 223-234. https://doi.org/10.1016/0346-251X(95)00010-H

Wenden, A. L. (1986). What do second language learners know about their language learning? A second look at retrospective accounts. Applied Linguistics, 7, 186-201. https://doi.org/10.1093/applin/7.2.186

Wenden, A. L. (1987). How to be a successful language learner: Insights and prescriptions from L2 learners. In A Wenden \& J Rubin (Eds.), Learner strategies in language learning (pp. 103-118). London, UK: Prentice-Hall International.

Yang, N. (1999). The relationship between EFL learners' beliefs and learning strategy use. System, 27(4), 435-600. https://doi.org/10.1016/S0346-251X(99)00048-2

Yang, J., \& Kim, T. (2011). Sociocultural Analysis of Second Language Learner Beliefs: A Qualitative Case

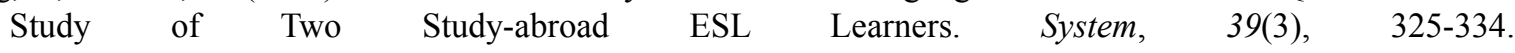
https://doi.org/10.1016/j.system.2011.07.005

\section{Copyrights}

Copyright for this article is retained by the author(s), with first publication rights granted to the journal.

This is an open-access article distributed under the terms and conditions of the Creative Commons Attribution license (http://creativecommons.org/licenses/by/4.0/). 